\title{
Clinical implications for the optometrist when assessing post LASIK patients
}

\author{
R Hansraj*
}

Discipline of Optometry, Faculty of Health Sciences, University of Kwa-Zulu, Natal, Private Bag X54001, Durban, 4000 South Africa

$<$ hansrajr@ukzn.ac.za>

Received 29 August 2013; revised version accepted 4 December 2013

\begin{abstract}
Laser assisted in situ keratomileusis (LASIK) has dominated the field of refractive surgery in the new millennium with many patients opting for it as an alternative to spectacles or contact lenses. LASIK appears to have been largely successful from a patient's perspective. Research in the area of refractive surgery has also been extensive with many studies highlighting the successes while others cautioning against its widespread use. Due to its popularity optometrists are bound to
\end{abstract}

encounter patients that have had LASIK. Most often optometrists are not directly involved in the surgical process although some are involved in comanagement. Irrespective of their involvement the optometrist should be knowledgeable in this field. This review highlights some aspects that all optometric clinicians should be aware of when managing post LASIK patients. (S Afr Optom 2013 72(4) 173-184)

Key words: Refractive surgery, LASIK, complications of LASIK, dry eye, LASIK induced ischemia.

\section{Introduction}

The concept of refractive correction other than with spectacles or contact lenses has spanned centuries from the time of ancient Chinese sleeping with sandbags on their eyes to do a form of corneal flattening to reduce myopia, to techniques involving the excimer laser. Many patients are now considering refractive surgery as the first option for the correction of refractive error, particularly LASIK $^{1,2}$ and optometrists are often approached for advice on this option. Furthermore patients are likely to consult optometrists post refractive surgery regarding their visual requirements. It is imperative therefore that optometrists familiarize themselves with the current techniques, indications, contraindications and clinical implications of LASIK.

LASIK induces changes that impact on the visual examination of a patient which include the reduction in best corrected visual acuity, poor night vision especially when driving, the need for dry eye management, an alteration in corneal sensitivity and integrity, monitoring for iatrogenic keractasia, possible inaccuracies of clinical measurements, the relevance of dilated fundus examinations post-operatively and a decrease in contrast sensitivity function. This paper will present an outline of what the optometrist should be aware of when consulting patients post LASIK.

\section{Blurred vision}

The goal of LASIK, like for any other form of refractive surgery, is to reduce the refractive error and hence improve unaided visual acuity (VA) ideally to 6/6. Therein lies the "perceived" success of refractive surgery. The optometrist examining a post LASIK patient, however, may expect to find VA poorer than 
$6 / 6$, herein also referred to as blurred vision, which may either be transient or permanent. Transient blurred vision, often in the form of haze, may occur in the first 12 to 24 hours due to small epithelial defects or stromal oedema, but should rarely last longer than about 48 hours $^{3}$. Corneal haze has been attributed to increased reflectivity of the anterior stromal keratocytes that are involved in the healing process ${ }^{4}$.

Persistent blurred vision, without spectacles or contact lenses, following LASIK can be related to variations in the healing response of each patient, an incorrect evaluation of pre-operative refractive error, incorrect computer software and spontaneous regression that limits the accuracy of the surgical outcome relative to the attempted correction ${ }^{5-7}$. These factors can result in the patient being overcorrected that is, a myope becoming hyperopic or a hyperope becoming more hyperopic. Early presbyopes and presbyopic patients will experience poor vision at near if they become even mildly hyperopic from an originally myopic state which may necessitate a hyperopic LASIK procedure, or the use of some other refractive surgery such as laser thermokeratoplasty ${ }^{5}$. On the other hand, undercorrections occur frequently in patients with high refractive errors ${ }^{8,9}$. Patients with residual refractive errors will complain of poor distance vision especially at night. Enhancements, which involves a retreatment, will thus be required and in some cases other forms of refractive surgery, other than LASIK, may need to be considered ${ }^{3,7}$. Alternatively, if further refractive surgery is not indicated, then the optometrist may provide spectacles or contact lenses in an attempt to correct the residual error.

Visual acuity may also be reduced by astigmatism induced post-operatively which tends to be 'withthe-rule' but more often irregular, and may be linked to a host of factors including thin corneal flaps, poor microkeratome function, incorrect markings, incorrect ablation profile, central island formations, decentration of the ablation zone, folds in Bowman's layer and variations during healing of the flap including flap wrinkling and torsion ${ }^{3,5,10-12}$. Residual astigmatism can be reduced by removing any interface material or debris from the flap ${ }^{10}$, however, if the cause is otherwise the optometrist may use rigid gas permeable lenses as a possible option for correction.

Patients may experience blurred vision after a period of time due to regression which refers to the post-operative refractive error slowly going back to the original refractive error. This can happen in the early post-operative period of between one and three months and generally stabilises between three and six months after the surgery ${ }^{13,14}$. Regression has, however, also been reported in the long term, minimum of 10 years post operatively, by Oruçoğlu et $a l^{15}$ who concluded that although a significant reduction in the myopic refractive error was achieved with LASIK, there was significant regression in the long term. Shojaei et $a l^{16}$ also reported that despite improvements in various nomograms, ablation profiles and technology, regression is still found in about a fifth of patients that undergo refractive surgery. Regression is said to occur more often in the high myopes and has been attributed to irregular re-epithelialization and hyperepithelialization, particularly at the edge of the ablated area $^{17}$. A $10 \mu \mathrm{m}$ epithelial thickness increase will result in $1 \mathrm{D}$ of regression ${ }^{18}$. Steroids are of little benefit in reversing regression therefore an enhancement may be necessary but can only be performed if there is sufficient residual corneal thickness ${ }^{10}$.

Optometrists can also expect to find a reduction in the best corrected VA (BCVA) obtainable following LASIK with refractive correction ${ }^{13,19-25}$. Optometrists therefore may find that it is not possible for the patient to achieve $6 / 6$ visual acuity with any residual prescription including the use of rigid contact lenses, or even through a pinhole. Several explanations have been put forward for the reduction of BCVA following refractive surgery including the induction of irregular astigmatism, poor post-operative healing, mechanical damage, inflammation, poor surgical technique, interface abnormalities and central islands ${ }^{26-28}$. Another explanation involves resultant corneal irregularity. Corneal shape may deviate from the simple sphero-cylinder of a fairly regular cornea to one of a more irregular cornea, as well as from a prolate (flatter in the periphery) shape to an oblate (steeper in the periphery) shape, resulting in a consequent increase in positive spherical aberrations hence limiting the spectacle corrected vision ${ }^{28,} 30$. Furthermore, it has been postulated that the transparency of the cornea could be compromised following surgical intervention due to an alteration in the arrangement of the collagen fibrils, which could impact on transparency ${ }^{31,32}$. The optical aberrations may be perceived as haloes, ghost images, and slight 
distortions and the optometrist may find patients complaining of shadows around objects. These optical aberrations may or may not interfere with normal VA but will affect the optical quality of the post-operative image hence any refractive error measured objectively may not be accepted subjectively, 33-35. All of these factors are expected to affect the refractive capability of the cornea and thus would impact on threshold VA following LASIK.

\section{Difficulties with night driving}

Optometrists are bound to encounter complaints from post LASIK patients about night vision especially when driving ${ }^{36}$. Fan-Paul et $a l^{37}$ predicted an increase in the number of patients complaining of scotopic and mesopic vision disturbances following refractive surgery and as more people undergo refractive surgery this issue could become a major public health problem. More recently, Zheng and Song $^{38}$ have reported the decline in night vision and experience of glare following LASIK as a major concern. These symptoms have been related to the induction of higher order aberrations such as spherical aberration after refractive surgery ${ }^{36}$. Furthermore, the debilitating effects of any small residual prescription will be experienced more under dim illumination. Night vision and glare vision thresholds of myopes appear to be reduced following LASIK with high myopes appearing to be affected more than low and moderate myopes ${ }^{39}$.

Night glare is often experienced as a result of the pupil diameter exceeding the optical zone created by LASIK hence more light enters through the peripheral cornea, which has not been reshaped resulting in myopic blur circles which degrades the retinal image ${ }^{40-42}$. Glare may also result from scattering through an oedematous cornea $^{42}$. Patients complain of haloes, ghosting and decreased vision at night ${ }^{3,41}$ which is not easily solved because increasing the optical zone diameter will necessitate a greater ablation depth, which in turn could result in the formation of central islands leading to astigmatism.

Difficulties with driving at night following LASIK have often been found due to glare ${ }^{43}$. El Danasoury ${ }^{44}$ reported that many patients experienced night glare, although many of them did not report it. In some patients night vision becomes so debilitating that they just stop driving ${ }^{39}$. In Germany, a study reported that seven out of ten patients were found unfit to drive at night according to German law, due to glare following $\mathrm{LASIK}^{43}$. Hence LASIK with certain occupations requiring good night vision must be considered with caution (pilots and truck drivers).

Alió, Piñero and Muftuoglu ${ }^{36}$ reported an improvement in night vision symptoms and spherical aberration induction with corneal wavefront guided ablations but in the retreatment procedure. The expected reduction of higher order aberrations with wavefront guided ablation has, thus far, not been achieved $^{45}$. For now, it is thus up to the optometrist assessing the post LASIK patient to determine the remediation before any retreatment is considered. Spectacles should be prescribed for any residual refractive error which can help optimize vision at night. Certain tints and coating on these spectacles can also be considered and tried in an attempt to minimize the glare effects. Rigid contact lenses may also be tried.

\section{Dry eyes}

Patients who undergo LASIK experience dry eye symptoms which are said to last for about one month after the surgery ${ }^{7,46-49}$. Tuisku et a ${ }^{50}$ however, reported that some patients are still symptomatic even five years later complaining of pain, burning, foreign body sensation and stickiness of eyelids. The dry eye condition is linked to many factors including damage to the conjunctival goblet cells, loss of corneal sensitivity, decrease in the blink rate and changes in corneal curvature ${ }^{7,}{ }^{48}, 51-53$. However, Tuisku et $a l^{50}$ reported, from a study on 20 subjects, that there were no clinical signs of a tear deficiency and that the symptoms may be more related to corneal neuropathy rather than a dry eye condition. Earlier, Toda et $a l^{49}$ had hypothesized that tear secretion from the lacrimal gland and mucin expression on the corneal epithelium may be suppressed by the damage to the corneal sensory innervation during flap formation in LASIK. This theory was supported by the finding that basic tear secretion is derived from the reflex mediated corneal sensitivity and therefore decreased sensitivity may result in hyposecretion ${ }^{54}$. The quality of vision can be affected by the induction of dry eye ${ }^{55}$. The dry eye condition may be treated with artificial tears, which may be required for long-term use but as the exact course is unknown this form of treatment may 
or may not be effective. Punctal plugs have also been found to be effective in managing dry eyes in post LASIK patients ${ }^{53}$.

\section{Photophobia}

Optometrists may find many post LASIK patients being more sensitive to light for variable periods following surgery. This finding has been related to scattering of light by the oedematous or irregular cornea $^{3}$. The use of tinted spectacles or sunglasses may provide some relief to the patient.

\section{Loss of corneal sensitivity}

Loss of corneal sensitivity has been associated with various refractive surgical procedures including LASIK. A confocal microscopic investigation of the normal cornea revealed that the nerves are located directly below Bowman's membrane and in the anterior stroma ${ }^{56}$. During LASIK the subbasal nerve fibre bundles and the superficial stromal nerves are cut, with only those in the hinge being spared $^{57,58}$. Hannush ${ }^{59}$ reported that the sub-basal corneal nerves return after about two years, while stromal nerves return by three years. A much shorter period of recovery of corneal sensation was reported by Kumano et a ${ }^{60}$ who found that by one year after LASIK the corneal sensitivity is not significantly different from the pre-operative values. Bragheeth and Dua $^{52}$ found that corneal sensitivity can be reduced for six months or more and that even though the corneal sensitivity may return it is uncertain whether corneal innervation ever fully returns to normal. Stapleton et $a l^{61}$ reported that there was only partial recovery of corneal sensitivity three months after surgery. Patel et $a l^{62}$ however, reported that the regrowth of sub-basal nerves is not complete until years after surgery.

The ablation depth and the ablation diameter were found to also impact on the decrease of corneal sensitivity and its recovery ${ }^{52,63}$. The deeper the ablation depth, the greater the decrease in corneal sensitivity and the longer the time taken for corneal sensitivity to recover.

Thus, the cornea is compromised when this sensory capability is drastically reduced. This is particularly important since good corneal sensitivity is essential for normal corneal structure and function as well as for the early detection and diagnosis of corneal disorders $^{52,57}$. Furthermore, corneal hypothesia may compromise the protective blink reflex, reduce the rate of mitosis of the corneal epithelium, delay wound healing and can be associated with decreased tear flow, all of which could have clinical implications ${ }^{64-66}$. A comprehensive and careful slit lamp examination should thus be conducted on all post LASIK patients.

\section{Weakening of corneal tissue}

During the ablation process a lot of debris is produced by the excimer laser ${ }^{58}$. Presently, it is not known where these by-products go to. Concern thus arises about the carcinogenic effects of these monatomic and diatomic particles, as well as, the effect of rapidly expanding gases on corneal tissue integrity ${ }^{58}$.

Furthermore, refractive surgery leads to a change in the biochemical composition, curvature and thickness of the cornea and it also alters natural tissue relationships ${ }^{1,8,59,67,68}$. There is a reduction in keratocyte density ${ }^{69}$ for at least five years after LASIK which is significant as keratocytes play a protective role against infection in the cornea as well as in wound healing. The cornea can also be mechanically weakened following LASIK due a poor wound healing response $\mathrm{e}^{70,71}$. Cronemberger et $a l^{72}$ found a significant reduction in ocular rigidity and corneal resistance after LASIK. Not surprisingly therefore an outbreak of Mycobacterium chelonae keratitis related to reduced corneal resistance was documented in a post LASIK patient, for which the cause was relatively unknown ${ }^{73,74}$.

Diffuse lamellar keratitis (DLK) is usually referred to as "Sands of Sahara" 8 . Causes seem to include contaminants on the microkeratome blade including residue of cleaning solutions, interface debris or bacterial toxins triggering off an inflammatory reaction, and thus anterior chamber activity $7,68,75$. These multi-focal infiltrates are culture-negative and noninfectious $^{76}$ and tend to occur within a week of surgery, however, sometimes may even occur several months after surgery ${ }^{77}$. Symptoms include pain and photophobia with signs of ciliary hyperaemia and lacrimation. Although visual acuity is not affected, visual quality is affected because of the scattering of light and may have a similar effect on vision as stromal haze has following $\mathrm{PRK}^{7}$. Treatment of 
DLK involves topical steroids or oral corticosteroids, together with the lifting and irrigation of the flap ${ }^{30,76,78}$. Again, optometrists should therefore be conducting a thorough slit lamp examination when examining post LASIK patients to be able to screen for such conditions.

The structural integrity of the cornea is compromised following $\mathrm{LASIK}^{79}$. The corneal flap is expected to be particularly weakened and thus must be monitored carefully especially in patients that are involved in contact sports ${ }^{80}$. Patients who are involved in such sport either professionally or for recreation should be advised accordingly. Possible complications of LASIK resulting from altitude and pressure changes on a weakened cornea remain unknown. A study by Dimmig and Tabin ${ }^{81}$ found a fluctuation of vision in three out of six LASIK patients who climbed up Mount Everest to $17600 \mathrm{ft}$. Clare et al ${ }^{82}$, however, indicated stable refraction in post LASIK eyes with prolonged exposure to altitude and hypoxia.

\section{Corneal ectasia}

Corneal ectasia, regarded as one of the more serious side effects of refractive surgery, refers to progressive thinning and weakening of the central cornea, and has been reported when the residual corneal thickness is less than $300 \mu \mathrm{m}^{7,43,70,84}$. Other risk factors associated with keractasia have since been identified and include a reduction in the biomedical strength of the cornea, forme fruste keratoconus, high myopia, a pre-operatively thin cornea, an unexpectedly thick flap and pregnancy ${ }^{84-87}$. It can occur a month or years after the surgery ${ }^{9,88-90}$. Wirbelauer and Pham ${ }^{91}$, following a pilot study, suggest the use of intraoperative optical coherence pachymetry as a safety feature to monitor flap and residual stromal thickness in an effort to avoid iatrogenic corneal ectasia.

It is important therefore that the optometrist assesses corneal topography on post LASIK patients with particular attention to the corneal apex so that any changes can be identified early on and treatment instituted. Penetrating keratoplasty or hard contact lenses may be required following the development of keractasia ${ }^{92}$ but more recently corneal cross linking, which appears to stabilize the cornea biomechanically, has been found to be effective in halting the progression of keractasia even though the sustainability of this effect is still questionable ${ }^{84,93}$. Fitting contact lenses after LASIK
Contact lens fitting has been reported as being more challenging and less successful following LASIK $^{23}$. Contact lenses post LASIK can be required for many reasons including keractasia, irregular astigmatism, epithelial flap defect et cetera, and can be fitted successfully following LASIK $^{94}$. More often it is rigid contact lenses that will be required as hydrogel lenses do not provide optimal vision performance due to the resultant irregular corneas ${ }^{23}$. Patients with significant corneal irregularity will require trial fitting using a wide spectrum of rigid contact lenses but often with one that extends over the sclera as well and has a reverse geometry profile ${ }^{23,94}$.

Determining the power of the Intraocular Lens (IOL)

Caution must be applied when determining the power of an IOL following cataract extraction in the post LASIK patient, as the keratometry readings as well as axial length measurements taken postoperatively are not always accurate ${ }^{1,95,96}$. Keratometry readings on a post LASIK cornea are not accurate as the refractive index of the cornea is altered following ablation ${ }^{96,97}$. The axial length appears to change due to a reported shift of the posterior cornea forward following LASIK $^{96}$. It is therefore important that these readings are taken pre-operatively and that the patient and future clinicians are able to access them.

There are numerous formulae that may be used when determining the IOL power ${ }^{95-97}$ but it is best that keratometry and axial length measurements are taken pre-operatively to allow for an accurate determination of IOL power. Furthermore, post LASIK patients requiring IOLs should be informed that the calculation of power for the IOL may not be accurate hence affecting their vision post cataract surgery.

\section{Retinal Integrity}

There have been cases of posterior segment complications following LASIK particularly in moderate to high myopes ${ }^{22,98,99}$. It has been suggested that any retinal haemorrhage may be due to some pre-existing pathology ${ }^{100}$. Hence, Arevalo et al ${ }^{101}$ suggested that all patients considering LASIK should have an OCT performed to identify at risk patients.

Excimer laser photoablation has, however, been found to generate an acoustic shock wave, which travels at the speed of sound through the cornea ${ }^{3,102,103}$. 
It has been postulated that this acoustic shock-wave may be damaging to the retina and that exposure of the retina to the laser may result in macular damage, posterior vitreous detachment, fibrosis, traction, cystoid macular edema and hole formation possibly due to vitreomacular interface and vitreoretinal changes ${ }^{99,102,104,105}$. RuizMoreno and Alió ${ }^{106}$ reported a low incidence of retinal disease including choroidal neovascularization, macular hole and macular haemorrhage following LASIK in myopic patients.

The application of the suction ring has also been linked to vitreoretinal changes even though the incidence of retinal detachment following LASIK has been found to be low ${ }^{98,101,107}$. Daftarian et a $l^{99}$ reported the suction ring to have caused an increase in the axial length of the eye and that $95.6 \%$ of their subjects who required treatment for retinal detachment had suffered a posterior vitreous detachment. The risk of retinal detachment in myopic eyes is definitely increased during the LASIK procedure $^{3,108}$ and a dilated fundus examination and assessment of macula integrity should be performed routinely by the optometrist examining post LASIK patients.

\section{Effects of an acute increase in Intraocular Pressure (IOP)}

Ocular health assessment of the post LASIK patient should also involve an assessment of the retinal nerve fibre layer which has recently become easier and more efficient with the use of optical coherence tomography. The IOP may reach up to $65 \mathrm{mmHg}$ during the lamellar cut with the microkeratome during LASIK and such high in-vitro IOP values can be dangerous for eyes at risk ${ }^{107,109-110}$. A study by Piette and colleagues ${ }^{111}$ found that a temporary elevation of IOP does result in measurable changes to the optic nerve head topography, and in particular the retinal nerve fibre layer thickness. The effect of this sudden increase and then release of IOP on the posterior segment of the eye during LASIK has not been fully investigated ${ }^{107,112}$. McCarty et $a l^{112}$ have reported a reduction in nerve fibre layer thickness following LASIK. Retinal nerve fibre damage, especially in high myopes who have thinner retinas, has also been reported by Shah and Ilango ${ }^{100}$. Furthermore, a study by Ozdamar and Ocakoglu ${ }^{113}$ found a compensatory temporary increase in blood flow to the lamina cribrosa region of the optic nerve head post-operatively suggesting LASIK-induced ischemia.
It is also postulated that the sudden increase in IOP exerts a mechanical stretch on the vitreous base along with the mechanical stress induced by the shock waves of the laser ${ }^{99,106}$ which could subsequently result in retinal haemorrhages and detachment. An assessment of the nerve fibre layer thickness, retinal integrity and central visual fields during an optometric examination of a post LASIK patient is thus warranted.

\section{Effect on contact tonometry readings}

Corneal changes during refractive surgery result in Goldmann tonometry underestimating IOPs in both myopes and hyperopes ${ }^{67,114-118}$. This underestimation was initially thought of as being due to the thinning of the stroma and flattening of the central cornea ${ }^{119}$. However, it is now believed to be multifactorial being influenced also by preoperative IOP, ocular rigidity, age, corneal epithelial thickness and tear film thickness ${ }^{72,120}$. These changes can result in the intraocular pressure being underestimated by between 3 to $10 \mathrm{mmHg} 7,100,115$. This underestimation is of particular concern since it could delay the diagnosis of elevated IOP in post LASIK patients ${ }^{116,121}$. Suggested alternatives for IOP assessment in post LASIK patients are the use of dynamic applanation tonometers such as the Pascal dynamic contour tonometer which is not influenced by corneal thickness or rigidity ${ }^{67}$ and more recently the Schiotz tonometer ${ }^{72}$ and the Tono-pen at the corneal limbus ${ }^{117}$. Furthermore, Fan et $a l^{118}$ found that the IOP measurement was more accurate when measured on the peripheral cornea rather than the central cornea in post LASIK patients. Optometrists should therefore interpret IOP readings taken with Goldman Applanation tonometry with caution and should also bear in mind that the greater the preoperative IOP the greater the expected underestimation of the IOP post-operatively ${ }^{120}$.

\section{Reduced contrast sensitivity}

Contrast sensitivity is important when considering visual quality. Any alteration or reduction in transparency of the optical components and in their modulation transfer function (MTF) will impact on contrast sensitivity. The optical quality of the cornea, hence its MTF, will determine the quality of the image produced and is dependent on two major parameters, namely the surface regularity and its shape $^{122}$. Following LASIK, there is a change in the 
shape of the cornea from prolate to oblate, which has been identified as the main reason for the reduction in optical quality and thus functional vision as it induces Seidel aberrations, which include spherical aberration, primary coma, astigmatism, trefoil, Petzval curvature and distortion ${ }^{4,122-127}$. Furthermore, Ondategui et al ${ }^{128}$ reported a decrease in the cornea's MTF following LASIK. This results in patients experiencing blurry vision especially under mesopic and scotopic conditions ${ }^{123,124,129}$.

Wavefront-guided custom treatments are said to reduce the incidence of higher order aberrations following LASIK and hence improve optical quality ${ }^{130}$. Shah ${ }^{100}$ had argued that wavefront corrections may not be able to eliminate the induction of higher order aberrations following LASIK completely due to the flap inducing its own series of aberrations. Furthermore, corneal surface irregularities such as flap striae, which induce significant optical aberrations and distortions but cannot be detected by commercial wavefront devices, will cause a degradation of optical performance ${ }^{35}$. Phusitphoykai et al ${ }^{131}$ and Keir et $a l^{132}$ found no statistically significant difference in the post-operative higher order aberrations following wavefront-guided LASIK compared to conventional LASIK.

Intraocular scatter has also been identified as a cause of a decrease in low contrast vision and contrast sensitivity following $\mathrm{LASIK}^{7,42}$. Intraocular scatter has been linked to micro-surface irregularities which often occur during LASIK due to the lamellar cut, leading to scattering of light across the retina ${ }^{33,128,133}$. Additionally, Perez-Gomez and Efron ${ }^{134}$ reported observing fine metallic debris at the corneal flap interface even six months after LASIK which can cause a certain amount of scattering of light and therefore impact on contrast sensitivity.

An initial decrease in contrast sensitivity particularly in the low and intermediate spatial frequencies may be expected ${ }^{135}$. This has been attributed to corneal haze. Arbelaez and Knorz ${ }^{136}$ and Holladay, Dudeja and Chang ${ }^{122}$ however, still noted this reduction in the longer term in post LASIK patients. MontesMico, Espana and Menezo ${ }^{137}$ found that contrast sensitivity was reduced even further under mesopic conditions particularly at high spatial frequencies as these frequencies are primarily affected by defocus and optical aberrations. This reduction in contrast sensitivity may be linked to the reduction in vision at night.

\section{Availability of donor corneas}

Corneas that have undergone LASIK cannot be used in full thickness penetrating keratoplasty due to their abnormal shape and altered biomechanical properties following surgery ${ }^{138}$. It is vital therefore that patients opting to be cornea donors must indicate if they have had previous corneal refractive surgery ${ }^{1}$. Considering the number of individuals that are opting for refractive surgery there is also considerable concern regarding the future availability of donor corneas.

\section{Conclusion}

Refractive errors change during a person's lifetime and the goal of optometric care is clear, comfortable and single vision for the patient throughout their life. Eye care in many countries has been compartmentalized into those services delivered by ophthalmologists and those by optometrists. As primary eye care practitioners, however, it becomes the responsibility of optometrists to be well versed and educated in all aspects of eye care even though they may not be directly involved in certain areas, such as refractive surgery. Optometrists will encounter post LASIK patients in their practice and they must be able to manage these patients effectively.

\section{References}

1. O'Keefe M, Kirwan C. Laser epithelial keratomileusis in 2010 - a review. Clinical and Experimental Ophthalmology 201038 183-191.

2. Ang M, Tan D, Mehta JS. Small incision lenticule extraction (SMILE) versus Laser In-Situ Keratomileusis (LASIK): study protocol for a randomized, non-inferiority trial. Trials 20121375.

3. Machat JJ. Excimer Laser Refractive Surgery-Practice and Principles. New Jersey: Slack Incorporated, 1996.

4. Moreno-Barriuso E, Lloves JM, Marcos S, Navarro R, Llorente L, Barbero S. Ocular aberrations before and after myopic corneal refractive surgery: LASIK induced changes measured with laser ray tracing. Investigative Ophthalmology and Visual Science 200142 1396-1403.

5. Buratto L, Ferrari M. Indications, techniques, results, limits and complications of Laser In-Situ Keratomileusis. Current Opinion in Ophthalmology 19978 59-66.

6. Condon PI, Mulhern M, Fulcher T, Foley-Nolan A, O'Keefe M. Laser intrastromal keratomileusis for high myopia and 
myopic astigmatism. British Journal of Ophthalmology 199781 199-206.

7. Chisholm C. Refractive surgery in practice: Part 5 Postoperative follow-up of the patient. Optician 2001221 16-21.

8. Bores LD. Refractive Eye Surgery, $2^{\text {nd }}$ ed. Boston: Blackwell Scientific Publications, 2001.

9. Zalentein WN, Tervo TM, Holopainen JM. Seven-year follow-up of LASIK for myopia. Journal of Refractive Surgery 200925 312-318.

10. Filatov V, Vidaurri-Leal JS, Talamo JH. Selected complication of radial keratotomy, photorefractive keratectomy, and Laser In Situ Keratomileusis. International Ophthalmology Clinics 199737 123-148.

11. Rama P, Chamon W, Genisi C, Azar DT. Excimer Laser Intrastromal Keratomileusis. In: Azar DT. Refractive Surgery, Connecticut: Appleton and Lange, 1997 p 451-470.

12. Sciscio A, Hull CC, Stephenson CG, Baldwin H, O'Brart D, Marshall J. Fourier analysis of induced irregular astigmatism. Photorefractive keratectomy versus Laser In Situ Keratomileusis in a bilateral cohort of hyperopic patients. Journal of Cataract and Refractive Surgery 200329 1709-1717.

13. Patel NS, Clinch TE, Weis JR, Ahn C, Lundergan MK, Heidenreich K. Comparison of visual results in initial and retreatment Laser In Situ Keratomileusis procedures for myopia and astigmatism. American Journal of Ophthalmology 2000 130 1-11.

14. Chayet AS, Assil KK, Montes M, Espinosa-Lagana M, Castellanos A, Tsioulias G. Regression and its mechanisms after Laser In Situ Keratomileusis in moderate and high myopia. Ophthalmology 1998105 1194-1199.

15. Oruçoğlu F, Kingham JD, Kendüşim M, Ayoğlu B, Toksu B, Göker S. Laser In Situ Keratomileusis application for myopia over minus 14 diopter with long-term follow-up. Int Ophthalmol. Published online: 10 June 2012. Available from:http://www.ncbi.nlm.nih.gov/pubmed/22684405 Accessed on 1 August 2012.

16. Shojaei A, Eslani M, Vali Y, Mansouri M, Dadman N, Yaseri M. Effect of timolol on refractive outcomes in eyes with myopic regression after Laser In Situ Keratomileusis: A prospective randomized clinical trial. American Journal of Ophthalmology 2012154 790-798.

17. Pallikaris IG, Siganos DS. Laser In Situ Keratomileusis to treat myopia: early experience. Journal of Cataract and Refractive Surgery 199723 39-49.

18. Lohmann CP, Güell JL. Regression after LASIK for the treatment of myopia: the role of the corneal epithelium. Seminars in Ophthalmology 199813 79-82.

19. Davidorf JM, Zaldivar R, Oscherow S. Results and complications of Laser In Situ Keratomileusis by experienced surgeons. Journal of Refractive Surgery 199814 114-122.

20. Barraquer CC, Gutiérrez AM. Results of Laser In-Situ Keratomileusis in hyperopic compound astigmatism. Journal of Cataract and Refractive Surgery 1999251198 1204.

21. El-Maghraby A, Salah T, Waring III GO, Klyce S, Ibrahim O. Randomized bilateral comparison of excimer Laser In Situ Keratomileusis and Photorefractive keratectomy or
2.50 to 8.00 diopters of myopia. Ophthalmology 1999106 447-457.

22. Stulting RD, Carr JD, Thompson KP, Waring III GO, Wile WM, Walker JG. Complications of Laser In Situ Keratomileusis for the correction of myopia. Ophthalmology 1999106 13-20.

23. Yeung KK, Olson MD, Weissman BA. Complexity of contact lens fitting after refractive surgery. American Journal of Ophthalmology 2002133 607-612.

24. Sekundo W, Bonicke K, Mattausch P, Wiegand W. Six-year follow-up of Laser In Situ Keratomileusis for moderate and extreme myopia using a first-generation excimer laser and microkeratome. Journal of Cataract and Refractive Surgery 200329 1152-1158.

25. Hansraj R, Oduntan AO, Rasengane TA. Visual acuity, contrast sensitivity and subjective perception of vision after LASIK refractive surgery. The South African Optometrist 200665 12-26.

26. Binder PS. Optical problems following refractive surgery. Ophthalmology 198693 739-745.

27. Manche EE, Maloney RK. Keratomileusis in situ for high myopia. Journal of Cataract Refractive Surgery 199622 1443-1450.

28. Hovanesian JA, Shah SS, Onclinx T, Maloney RK. Quantitative topographic irregularity as a predictor of spectacle-corrected visual acuity after refractive surgery. American Journal Ophthalmology 2000129 752-758.

29. Selier T, Kaemerer M, Mierdel P, Krinke H. Ocular optical aberrations after photorefractive keratectomy for myopia and myopic astigmatism. Archives of Ophthalmology 2000 118 17-21.

30. Chisholm C. Refractive reflections. Optician 200022029 33.

31. Foster W, Melching J, Heyd R, Atzler U, Dangel P, Schurenbery M, Kresse H, Busse H. Corneal wound healing after 193nm excimer laser radiation. Progress in Biomedical Optics - Proceedings in Ophthalmic Technologies IV 1994 2126 24-27.

32. Quantock AJ. The cornea is clear - but why? Optometry Today 200040 32-35.

33. Salchow DJ, Zirm ME, Stieldorf C, Parisi A. Comparison of objective and subjective refraction before and after Laser In Situ Keratomileusis. Journal of Cataract and Refractive Surgery 199925 827-835.

34. Karpecki PM. Dry eye in LASIK: clues to the cause. Review of Optometry Online 2001. Available from: http://www. revoptom.com/archive/dept/ro0601 op2.htm.Accessed November 2003.

35. Mrochen M, Semchishen V. From scattering to wavefronts - what's in between? Journal of Refractive Surgery 200319 S597- S601.

36. Alió JL, Piñero D, Muftuoglu O. Corneal wavefront-guided retreatments for significant night vision symptoms after myopic laser refractive surgery. American Journal of Ophthalmology 2008145 65-74.

37. Fan-Paul NI, Li J, Miller JS, Florakis GJ. Night vision disturbances after corneal refractive surgery. Survey of Ophthalmology 200247 533-546. 
38. Zheng H, Song L. Visual quality of Q-value-guided LASIK in the treatment of high myopia. Eye Science 201126208 210.

39. Hansraj R. Night vision of the Post-LASIK myope. The South African Optometrist 200766 138-146.

40. O'Brart DPS, Lohmann CP, Fitzke FW, Klonos G, Corbett MC, Kerr-Muir MG, Marshall J. Disturbances in night vision after excimer laser photorefractive keratectomy. Eye 19948 46-51.

41. Klyce, S. Night vision disturbances after refractive surgery: haloes are not just for angels. British Journal of Ophthalmology 200791 992-993.

42. Cerviño A, Villa-Collar C, Gonzalez-Meijome JM, FerrerBlasco T, García-Lázaro S. Retinal straylight and light distortion phenomena in normal and post-LASIK eyes. Graefes Archive for Clinical and Experimental Ophthalmology 2011249 15611566.

43. Tabb RL. Surgical and non-surgical techniques to correct refractive errors. Optometry Today 200141 34-38.

44. El Danasoury MA. Prospective bilateral study of night glare after Laser In Situ Keratomileusis with single zone and transition zone ablation. Journal of Refractive Surgery 199814 512-516.

45. Stonecipher KG, Potvin R, Meyer JJ, Durrie D, Stonecipher K. Refractive surgery outcomes comparison-all wavefrontguided versus a decision tree for selecting wavefront-guided or wavefront-optimized. US Ophthalmic Review 20125 1417.

46. Lenton LM, Albeitz JM. Effect of carmellose-based artificial tears on the ocular surface in eyes after Laser In Situ Keratomileusis. Journal of Refractive Surgery 1999 15 S227-S231.

47. Aras C, Ozdamar A, Bahcecioglu H, Karacorlu M, Sener B, Ozkan S. Decreased tear secretion after Laser In Situ Keratomileusis for high myopia. Journal of Refractive Surgery 200016 362-364.

48. Slade SG, Baker RN, Brockman DK. The Complete Book Of Laser Eye Surgery. Illinois: Sourcebooks, Inc, 2000.

49. Toda I, Asano-Kato N, Komai-Hori Y, Tsubota K. Dry eye after Laser In Situ Keratomileusis. American Journal of Ophthalmology 2001132 1-7.

50. Tuisku IS, Lindbohm N, Wilson SE, Tervo TM. Dry eye and corneal sensitivity after high myopic LASIK. Journal of Refractive Surgery 200723 338-342.

51. Donnenfeld ED, Solomon K, Perry HD, Doshi SJ, Ehrenhaus M, Solomon R, Biser S. The effect of hinge position on corneal sensation and dry eye after LASIK. Ophthalmology 2003110 1023-1029.

52. Bragheeth MA, Dua HS. Corneal sensation after myopic and hyperopic LASIK: clinical and confocal microscopic study. British Journal of Ophthalmology 200589 580-585.

53. Yung YH, Toda I, Sakai C, Yoshida A, Tsubota K. Punctal plugs for treatment of post-LASIK dry eye. Japanese Journal of Ophthalmology 201256 208-213.

54. Tseng S, Tsubota K. Important concept for treating ocular surface and tear disorders. American Journal of Ophthalmology 1997124 825-835.

55. Toda I, Yoshida A, Sakai C, Hori-Komai Y, Tsubota K.
Visual performance after reduced blinking in eyes with soft contact lenses or after LASIK. Journal of Refractive Surgery 200925 69-73.

56. Mandell RB. Contact Lens Practice. Chicago: Charles C Thomas, 1988.

57. Linna TU, Vesaluoma MH, Pe'rez-Santonja JJ, Petroll M, Alio' JL, Tervo TMT. Effect of myopic LASIK on corneal sensitivity and morphology of subbasal nerves. Investigative Ophthalmology and Visual Science 200041 393-397.

58. Vesaluoma M, Pérez-Santonja J, Petroll WM, Linna T, Alió J, Tervo T. Corneal stromal changes induced by myopic LASIK. Investigative Ophthalmology and Visual Science 200041 369-375.

59. Hannush S. What's new in refractive surgery? Review of Ophthalmology 2003. Available from: http:/www.revophth. com/index.asp?page=1-333.htm. Accessed December 2003.

60. Kumano Y, Matsui H, Zushi I, Mawatari A, Matsui T, Nishida T, Miyazaki M. Recovery of corneal sensation after myopic correction by Laser In Situ Keratomileusis with a nasal or superior hinge. Journal of Cataract and Refractive Surgery 200329 757-761.

61. Stapleton F, Hayward KB, Bachand N, Trong PH, Teh DW, Deng KM, Yang EI, Kelly SL, Lette M, Robinson D. Evaluation of corneal sensitivity to mechanical and chemical stimuli after LASIK: a pilot study. Eye Contact Lens 200632 88-93.

62. Patel SV, McLaren JW, Kittleson KM, Bourne WM. Subbasal nerve density and corneal sensitivity after Laser In Situ Keratomileusis: femtosecond laser vs mechanical microkeratome. Archives of Ophthalmology 2010128 1413-1419.

63. Nassaralla BA, McLeod SD, Nassaralla JJ Jr. Effect of myopic LASIK on human corneal sensitivity. Ophthalmology 2003 110 497-502.

64. Beuerman RW and Schimmelpfennig B. Sensory denervation of the rabbit cornea affects epithelial properties. Experimental Neurology 198069 196-201.

65. JordanA, Baum J. Basic tear flow. Does it exist? Ophthalmology 198087 920-930.

66. Martin XY, Safran AB. Corneal hypothesia. Survey of Ophthalmology 198833 28-40.

67. Pepose JS, Lim-Bon-Siong R, Mardelli P. Future shock: the long term consequences of refractive surgery. British Journal of Ophthalmology 199781 428-429.

68. Toda I. LASIK and the ocular surface. Cornea 200827 S70-76.

69. Erie JC, Patel SV, Mclaren JW, Hodge DO, Bourne WM. Corneal keratocyte deficits after photorefractive keratectomy and Laser In Situ Keratomileusis. American Journal of Ophthalmology 2006141 799-809.

70. Wang Z, Chen J, Yang B. Posterior corneal surface topographic changes after Laser in situ Keratomileusis are related to residual corneal bed thickness. Ophthalmology 1999106 406-410.

71. Philipp WE, Speicher L, Gottinger W. Histological and immunohistochemical findings after Laser In Situ Keratomileusis in human corneas. Journal of Cataract and Refractive Surgery 200329 808-820. 
72. Cronemberger S, Guimaraes CS, Calixto N, Calixto JMF. Intraocular pressure and ocular rigidity after LASIK. Arquivos Brasileiros de Oftalmologia 200972 439-443.

73. Chandra NS, Torres MF, Winthrop KL, Bruckner DA, Heidemann DG, Calvet HM, Yakrus M, Mondino BJ, Holland GN. Cluster of Mycobacterium chelonae keratitis cases following Laser In-Situ Keratomileusis. American Journal of Ophthalmology 2001132 298-299.

74. Freitas D, Alvarenga L, Sampaio J, Mannis M, Sato E, Sousa L, Vierira L, Yu MC, Martins MC, Hoffling-Lima A, Belfort R Jr. An outbreak of Mycobacterium chelonae infection after LASIK. Ophthalmology 2003110 276-285.

75. Sandoval HP, Crosson CE, Holzer MP, Vroman DT, Solomon KD. Residual cleaner after normal cleaning of Laser In Situ Keratomileusis instruments. Journal of Cataract and Refractive Surgery 200329 1727-1732.

76. Amano R, Ohno K, Shimizu K, Suzuki M, Aizawa D, Komatsu M. Late onset diffuse lamellar keratitis. Japanese Journal of Ophthalmology 200347 463-468.

77. Belda JI, Artola A, Alio J. Diffuse lamellar keratitis 6 months after uneventful Laser In Situ Keratomileusis. Journal of Refractive Surgery 2003 19 70-71.

78. Hoffman RS, Fine IH, Packer M. Incidence and outcomes of LASIK with diffuse lamellar keratitis treated with topical and oral corticosteroids. Journal of Cataract and Refractive Surgery 200329 451-456.

79. Kamiya K, Oshika T. Corneal forward shift after excimer laser keratorefractive surgery. Seminars in Ophthalmology 200318 17-22.

80. Tumbocon JAJ, Paul R, Slomovic A, Rootman DS. Late traumatic displacement of Laser In Situ Keratomileusis flaps. Cornea 200322 66-69.

81. Dimmig JW, Tabin G. The ascent of Mount Everest following Laser In Situ Keratomileusis. Journal of Refractive Surgery 200319 48-51.

82. Clare G, Pitts JA, Edgington K, Allan BD. From beach lifeguard to astronaut: occupational vision standards and the implications of refractive surgery. British Journal of Ophthalmology 201094 400-405.

83. Randleman JB, Woodward M, Lynn MJ, Stulting RD. Risk assessment for ectasia after corneal refractive surgery. Ophthalmology 2008115 37-50.

84. Li G, Fan ZJ. Peng XJ. Corneal collagen crosslinking for corneal ectasia of post-LASIK: one-year results. International Journal of Ophthalmology 20125 190-195.

85. Chisholm C. Refractive surgery in practice: Part 6 - Postoperative follow-up of the patient. Optician 2001222 20-25.

86. Giledi O, Daya SM. Unexpected flap thickness in Laser In Situ Keratomileusis. Journal of Cataract and Refractive Surgery 200329 1825-1826.

87. Hafezi F, Koller T, Derhartunian V, Seiler T. Pregnancy may trigger late onset of keractasia after LASIK. Journal of Refractive Surgery 201228 242-243.

88. Randleman JB, Russell B, Ward MA, Thompson KP, Stulting RD. Risk factors and prognosis for corneal ectasia after LASIK. Ophthalmology 2003110 267-275.

89. Piccoli PM, Gomes AA, Piccoli FV. Corneal ectasia detected 32 months after LASIK for correction of myopia and asymmetric astigmatism. Journal of Cataract and Refractive Surgery 200329 1222-1225.

90. Meghpara B, Nakamura H, Macsai M, Sugar J, Hidayat A, Yue BYJT, Edward DP. Keratectasia after Laser In Situ Keratomileusis: A histopathologic and immunohistochemical Study. Archives of Ophthalmology 2008126 1655-1663.

91. Wirbelauer C, Pham DT. Intraoperative optical coherence pachymetry during Laser In Situ Keratomileusis-first clinical experience. Journal of Refractive Surgery 200319 372-377.

92. Amoils SP, Deist MB, Gous P, Amoils PA. Iatrogenic keratectasia after Laser In Situ Keratomileusis for less than -4.0 to -7.0 diopters of myopia. Journal of Cataract and Refractive Surgery 200027 967-977.

93. Cheema AS, Mozayan A, Channa Prabjot. Corneal collagen corsslinking in refractive surgery. Current Opinion in Ophthalmology 201223 251-256.

94. Boshnick E. A New contact lens option for post LASIK patients. Refractive Eyecare June 2008: 1-3. Available from: http://eyefreedom.com/RERS1206-Boshnick-final. pdf. Accessed May 2012.

95. Huang SC, Chen HJ. Overview of laser refractive surgery. Chang Gung Medical Journal 200831 237-252.

96. Feiz V. Intraocular lens power calculation after corneal refractive surgery. Middle East African Journal of Ophthalmology 2010 17 63-68.

97. Mesa-Gutiérrez JC, Rouras-López A, Porta-Monnet J, Amías-Lamana V, Cabiró-Badimón I, Solanas-Garcia L. Intraocular lens power calculation after myopic LASIK with no previous data: a review of available methods. Journal of Clinical and Experimental Ophthalmology 201121000126.

98. Jory WJ. Refractive surgery today. Optometry Today 1996 36 33-35.

99. Daftarian N, Dehghan MH, Ahmadieh H, Soheilian M, Karkhaneh R, Lashay A, Mirshahi A, Parhizkar H, Kazemimoghadam M, Modarreszadeh M, Hashemi M, Fadaei M, Entezari M. Characteristics and surgical outcomes of rhegmatogenous retinal detachment following myopic LASIK. Journal of Ophthalmic and Vision Research 20094 151-159.

100. Shah S, Ilango B. Refractive surgery in practice: Part 3 Laser In Situ Keratomileusis (LASIK). Optician 2001221 16-22.

101. Arevalo JF, Rodriguez FJ, Rosales-Meneses JL, Dessouki A, Chan CK, Mittra RA, Ruiz- Moreno JM. Vitreoretinal surgery for macular hole after Laser Assisted In Situ Keratomileusis for the correction of myopia. British Journal of Ophthalmology 200589 1423-1426.

102. Goldstein BHS, Hersh PS. Corneal Topographic changes after laser refractive surgery. In: Wu HK, Thompson VM, Steinert RF, Hersh PS, Slade SG. Refractive Surgery. New York: Thieme, 1999 p101-123.

103. Mazur DO, Hollifield R, Gee W. Retinal detachment in myopic eyes after Laser In Situ Keratomileusis (letter to the editor). American Journal of Ophthalmology 2000129 823-824.

104.Janknecht P, Soriano JM, Hansen LL. Cystoid macular 
oedema after excimer laser photorefractive keratectomy. British Journal of Ophthalmology 199377681.

105.Chan CK and Lawrence FC. Macular hole after Laser In Situ Keratomileusis and photorefractive keratectomy. American Journal of Ophthalmology 2001131 666-667.

106. Ruiz-Moreno JM, Alio JL. Incidence of retinal disease following refractive surgery in 9239 eyes. Journal of Refractive Surgery 200319 534-547.

107.Luna JD, Reviglio VE, Juarez CP. Bilateral macular hemorrhage after Laser In Situ Keratomileusis. Graefe's Archive for Clinical and Experimental Ophthalmology 1999237 611-613.

108. Arevalo JF, Lasave AF, Torres F, Suarez E. Rhegmatogenous retinal detachment after LASIK for myopia of up to -10 diopters: 10 years of follow-up. Graefe's Archive for Clinical and Experimental Ophthalmology $2012250963-$ 970.

109. Claoue C. The future of refractive surgery. In: Claoue C. Laser and Conventional Refractive Surgery. London: BMJ Publishing group, 1996 p 377-380.

110. Sachs HG, Lohmann CP, Op de Laak JP. IOP in sections with two microkeratomes. Ophthalmology 199794707 709.

111. Piette S, Liebmann JM, Ishikawa H, Gurses-Ozden R, Buxton D, Ritch R. Acute conformational changes in the optic nerve head with rapid intraocular pressure elevation: implications for LASIK surgery. Ophthalmic Surgery Lasers and Imaging 200334 334-341.

112. McCarty TM, Hardten DR, Anderson NJ, Rosheim K, Samuelson TW. Evaluation of neuroprotective qualities of brimonidine during LASIK. Ophthalmology 2003110 1615-1625.

113. Ozdamar A, Ocakoglu O. Optic nerve head blood flow using scanning laser Doppler flowmetry after Laser In Situ Keratomileusis. Journal of Refractive Surgery 200319433 437.

114. Faucher A, Gregoire J, Blondeau P. Accuracy of Goldmann tonometry after refractive surgery. Journal of Cataract and Refractive Surgery 199723 832-838.

115. Montes-Mico R, Charman WN. Intraocular pressure after excimer laser myopic refractive surgery. Ophthalmic and Physiological Optics 200121 228-235.

116. Aristeidou AP, Labiris G, Katsanos A, Fanariotis M, Foudoulakis NC, Kozobolis VP. Comparison between Pascal dynamic contour tonometer and Goldmann applanation tonometer after different types of refractive surgery. Graefe's Archive for Clinical and Experimental Ophthalmology 2011249 767-773.

117. Li X, Li G, Liu L, Li J. Comparison of intraocular pressures at different points in human's cornea before and after Laser In Situ Keratomileusis with Tono-Pen tonometer. Journal of Huazhong University of Science and Technology (Medical Sciences) 201131 128-130.

118. Fan Q, Zhang J, Zheng L, Feng H, Wang H. Intraocular pressure change after myopic Laser In Situ Keratomileusis as measured on the central and peripheral cornea. Clinical and Experimental Optometry 201295 421-426.

119. Kohlhaas M, Lerche R-CH, Draeger J, Klemm M, Ehlers N,
Hjordtal J, Olsen H, Barraquer C, Barraquer JI, Flicker D, Rivera F, Carriazo C. The influence of corneal thickness and corneal curvature on tonometry readings after corneal refractive surgery. European Journal of Implant and Refractive Surgery 19957 84-88.

120. Chihara E, Takahashi H, Okazaki K, Park M, Tanito M. The preoperative intraocular pressure level predicts the amount of underestimated intraocular pressure after LASIK for myopia. British Journal of Ophthalmology 200589 160164.

121. Arimoto A, Shimizu K, Shoji N, Enomoto K, Kohara M. Underestimation of intraocular pressure in eyes after Laser In Situ Keratomileusis. Japanese Journal of Ophthalmology 200346 645-649.

122. Holladay JT, Dudeja DR, Chang J. Functional vision and corneal changes after Laser In Situ Keratomileusis determined by contrast sensitivity, glare testing, and corneal topography. Journal of Cataract and Refractive Surgery 199925 663-669.

123. Steele C. Wavefront assisted LASIK for perfect visual outcomes? Optometry Today 200141 42-46.

124. Waring III GO. Quality of vision and freedom from optical correction after refractive surgery. Journal of Refractive Surgery 199713 213-215.

125. Guirao A, Porter J, Williams DR, Cox IG. Calculated impact of higher-order monochromatic aberrations on retinal image quality in a population of human eyes. Journal of the Optical Society of America Optics Image Science and Vision 200219 1-9.

126. Chalita MR, Krueger RR. Correlation of aberrations with visual acuity and symptoms. Ophthalmology Clinics of North America 200417 135-42 v-vi.

127. Calvo R, Mclaren JW, Hodge DO, Bourne WM, Patel SV. Corneal aberrations and visual acuity after Laser In Situ Keratomileusis: femtosecond laser versus mechanical microkeratome. American Journal of Ophthalmology 2010 149 785-793.

128. Ondategui JC, Vilaseca M, Arjona M, Montasell A, Cardona G, Guell JL, Pujol J. Optical quality after myopic photorefractive keratectomy and Laser In Situ Keratomileusis: Comparison using a double-pass system. Journal of Cataract and Refractive Surgery 201238 16-27.

129. Patorgis CJ. Photostress recovery testing. In: Eskridge JB, Amos JF, Bartlett JD. Clinical Procedures in Optometry. Philadelphia: JB Lippincott Company, 1991 p482-486.

130. Aizawa D, Shimizu K, Komatsu M, Ito M, Suzuki M, Ohno K, Uozato H. Clinical outcomes of wavefront-guided Laser In Situ Keratomileusis: 6-month follow-up. Journal of Cataract and Refractive Surgery 2003; 29: 1507-1513.

131. Phusitphoykai N, Tungsiripat T, Siriboonkoom J, Vongthongsri A. Comparison of conventional versus wavefront-guided Laser In Situ Keratomileusis in the same patient. Journal of Refractive Surgery 200319 S217-S220.

132. Keir NJ, Simpson T, Jones LW, Fonn D. Wavefront-guided LASIK for myopia: effect on visual acuity, contrast sensitivity, and higher order aberrations. Journal of Refractive Surgery 200925 524-533.

133. Bennett AG, Rabbetts RB. Clinical Visual Optics. London: 
Butterworths, 1984.

134.Perez-Gomez I, Efron N. Confocal microscopic evaluation of particles at the corneal flap interface after myopic Laser In Situ Keratomileusis. Journal of Cataract and Refractive Surgery 200329 1373-1377.

135.Pérez-Santonja JJ, Sakla HF, Alió JL. Contrast sensitivity after Laser In Situ Keratomileusis. Journal of Cataract and Refractive Surgery 199824 183-189.

136. Arbelaez MC, Knorz MC. Laser In-Situ Keratomileusis for hyperopia and hyperopic astigmatism. Journal of Refractive Surgery 199915 406-414.

137. Montes-Mico R, Espana E, Menezo JL. Mesopic contrast sensitivity function after Laser In Situ Keratomileusis. Journal of Refractive Surgery 200319 353-356.

138. Michaeli-Cohen A, Lamber AC, Coloma F, Rootman DS. Two cases of a penetrating keratoplasty with tissue from a donor who had undergone LASIK surgery. Cornea 2002 21 111-113. 